\title{
SOBRE A LIBERDADE DA VONTADE: OBJEÇÕES DE HANNAH ARENDT À KANT
}

\author{
Elizabete Olinda Guerra \\ Universidade Federal de Santa Catarina
}

\begin{abstract}
The study aims to explore the objections that Arendt addresses to Kant regarding the question of free will. Arendt sees the will as being the source of action, capable of bringing something new to the world that cannot be explained by a chain of causality, as suggested by Kant in his Third Antinomy. Yet contrary to Kantian thought, Arendt defends the thesis that the will is its own sake, or not is a will, it is not possible to consider it only a tool of practical reason.
\end{abstract}

KEYWORDS: action, free will, pratical reason.

RESUMO: O estudo pretende explorar as objeções que Arendt dirige à Kant no que concerne à questão da vontade livre. Arendt considera a vontade como sendo a fonte da ação, capaz de trazer ao mundo algo novo, que não pode ser explicado por uma cadeia de causalidade, como sugere Kant em sua Terceira Antinomia. Ainda contrária ao pensamento kantiano, Arendt defende a tese de que a vontade é sua própria causa, ou não é uma vontade, não sendo possível considerá-la apenas um instrumento da razão prática.

PALAVRAS-CHAVE: ação, vontade livre, razão prática.

\section{INTRODUÇÃO}

O pensamento de Kant é presença e influência constante na obra de Hannah Arendt. A esta constatação chega-se não apenas pelo conhecimento de sua obra, mas pela voz da própria Arendt que em entrevista ao jornalista Günter Gaus declara ter lido Kant aos quatorze anos, e desde então ficara sabendo que iria estudar filosofia, guiada pela necessidade de compreender (ARENDT, 2008, p. 38). E em seu último ano de vida, recolhida e empenhada em escrever sobre a faculdade de julgar, ela escreve a Ludwig 
Greve e diz: "leio com extraordinário prazer o velho e bom Kant e não me preocupo com mais ninguém. Isso me deixa feliz" (ARENDT apud YOUNGBRUEHL, 1997, p. 405). Entretanto, no que diz respeito às suas análises sobre a vontade, presentes no segundo volume de sua obra - póstuma e inacabada - $A$ vida do espírito, em que Arendt ocupa-se com as faculdades espirituais, ou atividades da vita contempletiva, apesar de referenciar o pensamento kantiano em vários momentos ao longo da obra, Arendt posiciona-se de forma corajosamente crítica ao "velho e bom Kant".

As objeções arendtianas dirigidas à Kant no que concerne à questão da vontade referem-se principalmente a dois aspectos, a saber, ao argumento kantiano da causalidade pela liberdade da vontade, e à sua defesa da vontade livre como instrumento da razão prática. Aspectos que esta exposição pretende explorar na tentativa de esclarecê-los.

Em suas investigações acerca do querer, Arendt assume como premissa a "vontade como fonte da ação", o que significa considerar, kantianamente, a liberdade da vontade como o "poder para começar espontaneamente uma série de coisas ou estados sucessivos” (ARENDT, 2002, p. 91). Para Arendt, esta capacidade de iniciar algo novo faz parte da condição humana. Ideia que se torna mais compreensível por meio do argumento de Santo Agostinho outra grande influência no pensamento arendtiano - de que o homem pelo fato de ter nascido representa um novo começo. A questão colocada por Arendt, e que guiará suas reflexões sobre a vontade, é a de saber como essa faculdade, capaz de trazer algo novo ao mundo, pode funcionar no espaço das aparências, ou seja, em uma seara de factualidade que transforma a espontaneidade dos recém-chegados no "foi" dos fatos.

Ainda em sua obra anterior - $A$ condição humana, ao falar da ação como o poder de desencadear processos e trazer um novo começo à esfera pública, Arendt referencia esta definição kantiana da liberdade (da vontade), e embora pareça concordar parcialmente com Kant, tem o cuidado de esclarecer que para este pensador a ação está sujeita ao determinismo das leis naturais (ARENDT, 2001, p. 247). Nota-se que tanto a consideração da liberdade da vontade como sendo um processo de causa e efeito - causalidade -, bem como a sujeição da vontade ao determinismo das leis naturais, e ainda a consideração da vontade livre como instrumento da razão prática, são possibilidades que já parecem incomodá-la de tal maneira que anos mais tarde ela retomará estas reflexões na tentativa de desvincular a vontade de tais condições. 
Quando analisa o que chamou de "história da vontade", Arendt retoma tais considerações com mais profundidade, e apresenta suas objeções à Kant ao longo do capítulo sobre "o querer". Se em $A$ condição humana o privilégio é concedido à ação, em $A$ vida do espírito a privilegiada é a vontade, imprescindível para que a ação aconteça. Cabe ressaltar que para Arendt, que nutre especial simpatia pelo querer, "a vontade estaria inevitavelmente conectada a duas questões centrais da modernidade, quais sejam, liberdade e contingência” (ASSY, 2002, p. 36). Arendt, implícita ou explicitamente contrária ao pensamento de Kant e apoiando-se em Santo Agostinho, defende a ideia de que "a vontade é sua própria causa ou não é uma vontade” (ARENDT, 2002, p. 252).

\section{A liberdade da vontade como causalidade}

A definição kantiana da liberdade da vontade pela causalidade encontra-se na Crítica da razão pura, em B 476, no momento em que Kant faz sua "observação sobre a terceira antinomia"1. Grosso modo, Kant investiga se a causalidade produtora dos fenômenos é segundo as leis naturais ou é proveniente da liberdade. A causalidade por liberdade, apresentada por Kant no esquema teórico da terceira antinomia parece anunciar uma preocupação em assegurar certeza ao conhecimento, bem como uma tentativa teórica de garantir uma futura teoria da moralidade. Desse modo, na solução à terceira antinomia Kant apresenta como problemas: conciliar uma causalidade por liberdade incondicionada com a causalidade da natureza, e também estabelecer aquela causalidade como causa espontânea na determinação da vontade (PERIN, 2001, p. 15).

Arendt interpreta "aquilo que na questão acerca da liberdade da vontade desde sempre causou um tão grande embaraço à razão especulativa" (KANT, 2008 p. 408), ou seja, "o poder de começar espontaneamente uma série de coisas sucessivas ou estados”, citado por Kant, como sendo reflexo das suspeitas em relação à faculdade da vontade, que refletiam uma relutância

\footnotetext{
${ }^{1}$ Cabe ressaltar que Kant utiliza o termo "antinomia" no sentido de afirmações contraditórias (ou conflitos transcendentais), definidas por tese e antítese, que são igualmente provadas como válidas pela razão. Assim sendo, a terceira antinomia apresenta como afirmações supostamente contraditórias, a tese de que "a causalidade segundo as leis da natureza não é a única de onde podem ser derivados os fenômenos do mundo em seu conjunto. Há ainda uma causalidade por liberdade que é necessário admitir para explicá-los" com a antítese de que "não há liberdade, mas tudo no mundo acontece unicamente em virtude das leis da natureza" (CRP B 472/473).
} 
aguda em conceder aos seres humanos um poder absoluto sobre seus próprios destinos. O próprio Kant constata que esta liberdade espontânea, ou "causalidade incondicionada", é a verdadeira pedra de escândalo para a filosofia que tem dificuldades insuperáveis para aceitá-la. Cabe ressaltar que o contexto no qual se inserem estas análises é o do período pós-medieval e o do surgimento da era moderna, ou era do progresso, momento em que os seres humanos encontravam-se desprotegidos de qualquer providência ou orientação divina. Arendt salienta que este "poder para começar" é distinto do livre arbítrio, ou do poder de escolha entre dois ou mais objetos dados, e que depois destas definições kantianas passou a ser comum equacionar "querer" e "ser". Por "livre arbítrio", Arendt entende que seja a decisão entre coisas possíveis e dadas a nós como simples potencialidades, já o poder de começar algo realmente novo não pode ser precedido de qualquer potencialidade, que figuraria como uma das causas do ato realizado.

Ao refletir sobre "o problema do novo", Arendt elenca as objeções levantadas pelos filósofos contra a faculdade da vontade, ou seja, contra a existência desta faculdade, contra a noção de liberdade que está implícita nesta faculdade e contra a contingência que adere a uma vontade livre. Arendt acredita que um ato livre é um ato que por definição se pode deixar de realizá-lo. Desse modo, as objeções supracitadas aplicam-se mais à vontade como órgão para o futuro do que para a noção de livre arbítrio. Neste ponto, encontra-se a objeção arendtiana ao exemplo utilizado por Kant para explicar a "causalidade pela liberdade" ou "a faculdade de começar espontaneamente uma série no tempo". Kant diz:

Quando agora (por exemplo) me levanto da cadeira, completamente livre e sem a influência necessariamente determinante de causas naturais, nesta ocorrência, com todas as suas conseqüências naturais, até o infinito, inicia-se absolutamente, uma nova série, embora quanto ao tempo seja apenas a continuação de uma série precedente. (...) $\mathrm{O}$ acontecimento sucede certamente a essas ações naturais, mas não deriva delas, e deverá, portanto considerar-se, em relação à causalidade, que não ao tempo, o começo absolutamente primeiro de uma série de fenômenos (KANT, 2008, p. 410).

Para Arendt, a noção de começo absoluto é bastante problemática, pois, uma série começando no mundo pode apenas ter relativamente um 
primeiro começo, sendo sempre precedida de algum outro estado de coisas. Arendt acredita que à pessoa do pensador, isto também se aplica, "visto que eu, que penso, jamais deixo de ser uma aparência entre aparências, por mais que consiga retirar-me dessas aparências espiritualmente" (ARENDT, 2002, p. 208). De acordo com Arendt, a hipótese de um começo absoluto remonta à doutrina bíblica da criação ex nihilo, ou vinda do nada. E suas palavras são enfáticas:

Há algo de fundamentalmente errado no exemplo de Kant. Somente quando ele, ao levantar-se da cadeira, tem em mente algo que deseja fazer é que esse "acontecimento" começa uma "nova série"; se não é esse o caso, se ele habitualmente se levanta a essa hora ou se levanta-se para pegar alguma coisa de que precisa para sua ocupação do momento, este acontecimento é, ele mesmo, "a continuação de uma série precedente” (ARENDT, 2002, p. 209).

Arendt especula acerca da possibilidade de Kant ter feito uma omissão em seu exemplo. Kant poderia ter claro para si o "poder de espontaneamente começar”, e poderia estar preocupado com uma possível reconciliação entre uma "nova série de atos e estados" e o contínuo do tempo que esta nova série irrompe. Mesmo assim, a solução possível para a época teria sido a distinção de Aristóteles entre potência e ato, a qual Arendt também não concorda e argumenta, por exemplo, não ser possível alguém sustentar que a sinfonia produzida por um compositor fosse possível antes de ser real. Para Arendt, a ideia de a sinfonia ser possível, isto é, de não ser impossível realizá-la, é bem diferente da possibilidade desta sinfonia existir em potencialidade, esperando por algum compositor que a tornasse real.

Em busca de apoio à sua defesa da existência da vontade livre, Arendt referencia os argumentos de Henri Bergson, para o qual a maioria dos filósofos é incapaz de conceber uma novidade radical ou a imprevisibilidade, pois mesmo os poucos que acreditam no livre arbítrio, acabam reduzindo-o a uma simples escolha entre duas ou mais opções, sendo que a vontade fica restrita a realizar uma destas escolhas (ARENDT, 2002, p. 210). Para Arendt, estes filósofos parecem nunca ter tido a noção de uma atividade que fosse inteiramente nova, como é o caso da ação livre, pois para a maioria deles o que impera é o determinismo. 
Ainda apoiada em Bergson, Arendt aborda outro aspecto da questão do ato livre ao apontar que do ponto de vista da memória, ou seja, olhandose retrospectivamente, todo ato livre perde seu teor de contingência pelo impacto da realidade. Em outras palavras, ao se tornar parte da realidade em que vivemos, o ato livre passa a ser um fato realizado e inseparável desta realidade. Este ato terá o aspecto de necessidade e será impossível de ser removido do pensamento. De acordo com Arendt, a contingência irrompeu como realidade apenas nos primeiros séculos da Era Cristã por causa da doutrina bíblica, posto que para a filosofia clássica tenha sido o máximo da falta de sentido. A doutrina bíblica opunha a contingência à necessidade, a particularidade à universalidade e a vontade ao intelecto, assegurando desse modo um lugar para o contingente. Para Arendt, o preconceito original contra a contingência, a particularidade e a vontade sobreviveu profundamente ao desafio até a Era Moderna. Segundo Arendt, a filosofia religiosa e medieval, assim como a secular e moderna encontraram diversas maneiras de assimilar a vontade, o órgão da liberdade e do futuro, à ordem mais antiga das coisas.

A vontade livre concebida como livre escolha, ou entendida como a liberdade de começar algo novo, na concepção de Arendt, parece ser absolutamente incompatível não apenas com a divina Providência, mas também com a lei da causalidade. Nossa autora acredita que a liberdade da vontade não pode ser provada, mas pode ser pressuposta pela força ou fraqueza da experiência interior, ou melhor, por uma força de afirmação ou de negação. Está claro para Arendt que a faculdade necessária para se executar os comandos é a vontade, e que a não plausibilidade deste pressuposto devese às nossas experiências externas no mundo das aparências, onde, a despeito do que disse Kant, raramente começamos uma nova série. Ressalta-se que apesar da crença arendtiana na espontaneidade livre, Arendt constata que os atos livres são mesmo excepcionais. Novamente é Bergson que ela referencia, para o qual "cada um de nós tem o conhecimento imediato de sua espontaneidade livre", e que "embora sejamos livres quando queremos nos voltar para nós mesmos, raramente queremos fazer isto" (BERGSON apud ARENDT, 2002, p. 211). Na realidade, apesar de acreditar na existência da vontade livre que pode gerar ações espontâneas, Arendt reconhece que são os hábitos que tomam conta da grande maioria dos nossos atos, assim como os preconceitos são responsáveis pela maioria dos nossos juízos cotidianos. 
Após explorar as análises de Santo Agostinho, considerado por Arendt como "o primeiro filósofo da vontade", mais uma vez a definição kantiana da "faculdade de começar espontaneamente uma série no tempo" é invocada pela pensadora alemã. Arendt debate-se para tentar compreender o embaraço de Kant ao lidar com a questão do começo, e especula:

Se Kant tivesse conhecido a filosofia da natalidade de Santo Agostinho provavelmente teria concordado que a liberdade da espontaneidade relativamente absoluta não é mais embaraçosa para a razão humana do que o fato de os homens nascerem continuamente recém-chegados a um mundo que os precede no tempo (ARENDT, 2002, p. 267).

Santo Agostinho faz a distinção entre o principium do céu e da terra, e o initium do homem. Nesse caso, o homem viera ao mundo para que este tivesse um começo. E de acordo com Arendt, a distinção entre um começo "absoluto" e um começo "relativo", aponta para o mesmo fenômeno descrito por Santo Agostinho, que tentara dar resposta à difícil questão da criação de coisas novas por um Deus eterno. Guiado pela necessidade de refutar o conceito cíclico de tempo defendido pelos filósofos, Santo Agostinho surpreende ao defender a necessidade da criação do homem ter sido separada de todas as outras criaturas, e acima delas. Assim sendo, o homem representa o começo, um começo que jamais existira antes dele. E, além disso, o homem foi criado no singular para que pudesse propagar-se a partir de indivíduos, enquanto as demais criaturas foram criadas no plural, ou seja, como começos de espécies. Esta individualidade do homem é o que o designa como "pessoa”, e é manifestada por sua vontade. Sintetizando a argumentação agostiniana, Hannah Arendt percebe que "o homem é posto em um mundo de mudança e movimento como um novo começo porque sabe que tem um começo e que terá seu fim” (ARENDT, 2002, p. 266), e já que é um ser que possui um começo e que corre para seu fim, o homem pôde ser dotado da capacidade de querer ou não querer. Nesse ponto, as especulações de Arendt se dirigem ao pensamento de Santo Agostinho, pois se ele tivesse levado a cabo as suas próprias especulações, teria definido os homens não como mortais, como pensavam os gregos, mas sim como "natais", e teria definido a liberdade da vontade não como o livre arbítrio entre querer e não querer, mas como a liberdade expressa por Kant em sua Crítica da razão pura, ou seja, a liberdade "de começar espontaneamente uma série no tempo". 
Considerando, obviamente, que este começo não caísse numa rede de causalidade e de determinismo, mas que representasse verdadeiramente algo novo, espontâneo e inusitado, um ato livre.

Ao ato livre, Arendt concede uma "espontaneidade desconcertante", pois acredita que um ato só pode ser chamado de livre se não for afetado ou causado por alguma coisa que o preceda, e que exija que este ato seja transformado em uma causa do que quer que venha a seguir. Se considerado desta forma, e se obtiver êxito, todo ato livre será a continuação de uma série precedente, o que para Arendt representa a negação da experiência de liberdade e novidade, ou seja, segue um caminho oposto ao que ela acredita que seja um novo começo.

Arendt sugere a palavra "revolução" para dissolver o "embaraço de Kant ao lidar com um poder de começar espontaneamente uma série de coisas ou estados sucessivos", ou seja, o embaraço kantiano em lidar com um "começo absoluto, que em virtude da inquebrantável seqüência do contínuo do tempo seguirá, entretanto, sendo sempre a continuação de uma série precedente" (ARENDT, 2002, p. 339). Isto, pelo fato de a palavra "revolução" ter mudado seu significado durante as últimas décadas do século XVIII, não possuindo mais o sentido astronômico e assumindo o sentido de um acontecimento sem precedentes.

Teórica política sempre atenta aos acontecimentos que ocorrem na esfera pública, Arendt dedicou-se com afinco à tarefa de entender as Revoluções, suas características e conseqüências, reflexões que se encontram presentes em sua obra $D a$ revolução, bem como em outros escritos políticos. Contudo, seu intuito ao abordar esta temática em $A$ vida do espírito é apenas o de esclarecer o que verdadeiramente entende que seja um novo começo, ou um ato novo que emerge sendo capaz de mudar a ordem estabelecida, por assim dizer. Nesse sentido, Arendt cita uma espécie de "revolução" ocorrida na França em 1793, que por um curto período representou um novo começo, quando os franceses decidiram que a proclamação da República ocorrida em 1792 seria um novo começo para a história humana, assim, o ano de 1793 seria considerado a inauguração do Ano II, acarretando mudanças significativas no calendário que foram extintas por volta de 1805. Mesmo tendo fracassado, esta tentativa do estabelecimento de um novo começo é significativa para Arendt, e parece vir ao encontro de sua crença na possibilidade de localização de novos começos absolutos no tempo. 
Outro exemplo de revolução utilizado por Arendt para ilustrar suas reflexões acerca do que entende que poderia ter sido um "novo começo", é o da Revolução norte-americana. De acordo com sua análise, quando os homens de ação, ou os fundadores da República norte-americana que queriam mudar o mundo, tiveram consciência de que suas ações poderiam efetivamente postular uma nova ordem, começaram a vasculhar a história a procura de ajuda. Começaram, por exemplo, a repensar o Pentateuco e a Eneida, lendas fundadoras que pudessem lhes dizer como resolver o problema do começo. Segundo Arendt, o começo seria um problema porque sua própria natureza traz em si o elemento da arbitrariedade. Foi exatamente nesse ponto que os fundadores se depararam com o que ela chamou de abismo da liberdade, pois sabiam que tudo o que fizessem neste momento poderia ser deixado de fazer. Aliás, Arendt percebe que os fundadores norteamericanos estavam bem familiarizados com a Antiguidade romana e também com a Bíblia, e talvez tenham retirado destas velhas lendas a distinção decisiva entre a simples liberação e a verdadeira liberdade. Arendt diz,

As lendas fundadoras com seu hiato entre a liberação e a constituição da liberdade, indicam o problema sem resolvê-lo. Apontam para o abismo do nada que se abre antes de qualquer ação que não pode ser explicada por uma cadeia segura de causa e efeito e que tampouco se explica pelas categorias aristotélicas de potência e ato (ARENDT, 2002, p. 341).

Arendt atenta para o fato de que no contínuo de tempo normal todo o efeito transforma-se imediatamente em uma causa de futuras ocorrências. Porém, quando a cadeia causal é quebrada - e isto ocorre após a liberação não resta nada em que o iniciante possa se agarrar, já que o pensamento de um começo absoluto elimina a seqüência de temporalidade tanto quanto o pensamento de um fim absoluto. Isto significa "pensar o impensável”, conclui Arendt, uma vez que nem o exemplo bem sucedido da fundação de Roma, no qual os homens de ação buscavam referência, representava um começo absolutamente novo. Pois, de acordo com os versos de Virgílio, Roma era o ressurgimento de Tróia, e o restabelecimento de uma CidadeEstado que a precedera. Desse modo, a linha de continuidade do tempo exigida pela tradição nunca teria sido quebrada, e a fundação de Roma ou o renascer de Tróia, seria a primeira de uma série de renascenças que fizeram a história da cultura e da civilização européia. 
Para Arendt, a importância destas análises se deve ao fato destas deixarem claro que os homens, ou seguiam a tutela da Igreja e acreditavam no Deus criador e responsável pela criação do céu e da terra, ou voltavam-se para a Antiguidade, fazendo com que seus primeiros passos secularizados pudessem ser guiados por um saber antigo, que considerava a fundação de Roma uma espécie de renascer e não um novo começo capaz de quebrar o contínuo do tempo.

Cabe ressaltar que a atenção dirigida por Arendt aos homens de ação fora guiada pela esperança de encontrar em seus feitos a noção de liberdade, "purgada das perplexidades causadas nos espíritos humanos pela reflexividade das atividades do espírito - a inevitável repercussão do ego volitivo sobre si mesmo” (ARENDT, 2002, p. 347). Mas, nossa pensadora alemã teve suas esperanças frustradas e ao invés de encontrar exemplos de ações espontâneas, reflexos da liberdade da vontade em trazer um novo começo ao mundo, encontrou a percepção de que cada novo começo representava apenas uma "reafirmação melhorada do velho". Arendt constata que o abismo de pura espontaneidade foi coberto com o mecanismo típico da tradição ocidental, que considera a liberdade a razão de ser de toda política, mas adverte que a liberdade apenas sobreviveu em sua integridade original na teoria política, com suas promessas utópicas e infundadas de um "reino de liberdade".

\section{A vontade livre como instrumento da razão prática}

Em sua abordagem histórica da faculdade espiritual da vontade, Arendt considera que o único grande pensador verdadeiramente irrelevante neste contexto seria Kant. Muito embora, admita que somente Kant pudesse ser comparado a Duns Scotus ${ }^{2}$ em seu compromisso com a liberdade. Arendt constata que a concepção kantiana de vontade é "um Vernunftwille não

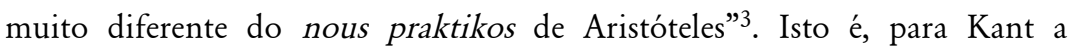

\footnotetext{
2 De acordo com as análises de Arendt, Duns Scotus confere primazia à faculdade da vontade. Para Scotus a vontade é autônoma, e pode não apenas rejeitar os ditames da razão como também resistir aos desejos e apetites mais fortes. Nesse caso, o indivíduo pode querer ou não querer o objeto apresentado pela razão ou pelo desejo. Esta seria a verdadeira liberdade humana, pois a vontade livre não pode ser coagida a querer uma vez que produz seu próprio ato.

3 Ressalta-se que neste trabalho, as referências a autores como Henri Bergson, Aristóteles, Duns Scotus, Tomás de Aquino e Santo Agostinho, são baseadas apenas nas reflexões de Hannah Arendt
} 
vontade não é uma faculdade especial do espírito distinta do pensamento, mas sim razão prática. A vontade em Kant não é a sua própria causa, nem é a liberdade de escolha, ou livre arbítrio, "a vontade de Kant é encarregada pela razão de ser seu órgão executivo em todas as questões de conduta" (ARENDT, 2002, p. 299). Desse modo, para Arendt, a espontaneidade pura que Kant chamou com freqüência de "espontaneidade absoluta" só existe em pensamento.

Cumpre constatar, que ao expor suas intenções acerca do estudo da faculdade da vontade, Arendt observa que traçar sua história seria tarefa que traria dificuldades, a começar pelo fato da vontade ter sido ignorada pela Antiguidade grega, e de não se ter ouvido falar da vontade até o primeiro século da Era Cristã. ${ }^{4}$ Período que trouxe consigo a dificuldade em conciliar a fé em um Deus todo-poderoso com as alegações de uma vontade livre, e que se estendeu até a Era Moderna. Arendt percebe que na modernidade a vontade livre ou encontra-se em choque com a lei da causalidade, como vimos anteriormente, ou traz dificuldades de conciliação com as leis da História. Nota-se que as dificuldades encontradas por Arendt em seu percurso histórico não são menores que a complexidade de sua objeção ao pensamento kantiano acerca da vontade livre. $\mathrm{E}$ isso, não se deve apenas ao fato da questão da liberdade da vontade ser central na filosofia de Kant, mas também pela falta de uma argumentação de maior consistência por parte de Hannah Arendt, o que, certamente, é devido à incompletude de sua última obra - $A$ vida do espírito - organizada e publicada postumamente.

Percebe-se, grosso modo, que grande parte da argumentação de Arendt, e, sobretudo das considerações de Santo Agostinho e Duns Scotus sobre a vontade, que ela julga importantes e com as quais se identifica, contrapõem-se à defesa kantiana da vontade livre como razão prática. A perspectiva arendtiana tem o sentido de dar à vontade livre o seu lugar de direito, por assim dizer, de garantir não apenas a sua existência, mas a sua

acerca da filosofia de tais autores, presentes principalmente em sua obra $A$ vida do espírito, e não em seus textos originais.

${ }^{4}$ Cabe salientar que com o advento do cristianismo, a faculdade da vontade foi considerada crucial para determinar tanto a beatitude do céu como o tormento do inferno como condições da vida futura, ou da vida eterna, de um indivíduo. Paulo era visto por Arendt como o fundador da religião e também da filosofia cristã, pelo fato de ter descoberto que o eu-quero é diferente do eu-posso, ou seja, que não era possível fazer o que bem queria. Arendt constatou que durante séculos a autoridade da Igreja manteve as oscilações da vontade em suspensão, refreando a ação pela ameaça da danação. (Kohn, 2004, p.24-25). 
independência das demais atividades espirituais. Para Arendt, "a vontade que é a primeira das faculdades espirituais, reatualiza no homem as possibilidades de renascimento sob o aspecto da espontaneidade e da liberdade" (KRISTEVA, 2002, p. 189). Lembrando que, em Arendt, a liberdade da espontaneidade é inseparável da condição humana, sendo a vontade o seu órgão espiritual.

O pensamento de Duns Scotus sobre a vontade agrada Arendt sobremaneira, e lhe serve de apóio e inspiração. Scotus, por um retorno original e pessoal ao pensamento de Santo Agostinho, restaura o primado da vontade sobre o intelecto e afirma a singularidade de cada ser que nasce. Arendt percebe que a primazia da vontade é provada por Duns Scotus com tanta plausibilidade quanto o intelecto é provado por São Tomás de Aquino. Desse modo, São Tomás, antecipa o pensamento de Kant e argumenta que a vontade é um órgão executivo necessário para executar os insigts do intelecto, ou seja, é uma faculdade meramente subserviente. Já Duns Scotus sustenta que é o intelecto que serve à vontade, fornecendo-lhe seus objetos, bem como o conhecimento necessário. Em outras palavras, em Scotus, o intelecto precisa da vontade para direcionar sua atenção e só pode funcionar adequadamente quando seu objeto é confirmado pela vontade. Para Scotus, a vontade é o que há nos seres humanos que os torna capazes de transcender suas próprias limitações e sua finitude absoluta, E Arendt parece mostrar-se em plena concordância com estes argumentos.

É também nas considerações de Scotus sobre a lei da causalidade que Arendt se apóia para sustentar sua própria argumentação. A lei da causalidade na versão aristotélica, conhecida por Scotus, era o que aparentemente ia contra a liberdade da vontade de querer ou não querer. Para Aristóteles, a cadeia causal tornava o movimento inteligível e o levava a uma fonte imóvel, o "motor imóvel", ou seja, uma causa que não é ela mesma causada. Scotus questiona a noção de cadeia de causalidade que siga uma linha contínua por meio de uma sucessão de causas suficientes e necessárias, e que chega a uma causa primeira para evitar o regresso ao infinito. Scotus rejeita a ideia de a vontade ser movida por um objeto exterior a ela, e também a ideia contrária de que a vontade é onipotente, chegando a uma posição intermediária capaz de salvar os fenômenos: a liberdade e a necessidade. Desse modo, os fenômenos seriam governados pela contingência. 
Arendt constata que o caráter contingente dos processos, defendido por Duns Scotus, contrapõe-se a toda a tradição filosófica. Pois, esta noção de contingência corresponde às experiências do ego volitivo, que no ato da volição sabe-se livre. Pelo relato de Arendt percebe-se que Scotus tinha consciência de não haver resposta real para a questão sobre o modo de conciliar a liberdade e a necessidade. Muito embora, pelo seu modo de pensar a liberdade e a necessidade como diferentes dimensões espirituais, não havia necessidade que houvesse tal conciliação. E nesse caso se houvesse algum conflito seria entre o ego pensante e o ego volitivo, em que a vontade que dirige o intelecto faria com que o indivíduo perguntasse o "por quê?" (ARENDT, 2002, p. 290). A resposta, obviamente, seria dada pelo intelecto, já que a vontade é incapaz de querer de forma retroativa. Note-se que a questão é sugerida pela vontade, o que faz com que Arendt designe a vontade como um "agente causativo", ou a fonte de toda a ação. Podemos entender o que Arendt quer dizer quando fala da vontade como agente causativo por meio destas suas palavras:

Para falar em termos de causalidade, primeiro a vontade causa volições, e tais volições causam, então, certos efeitos que nenhuma vontade pode desfazer. $\mathrm{O}$ intelecto, tentando fornecer à vontade uma causa explanatória que lhe abrande a indignação quanto à própria fraqueza, fabricará uma história que faça com que os dados se encaixem. Sem pressupor a necessidade, faltaria à história toda a coerência (ARENDT, 2002, p. 191).

Para Scotus a oposição decisiva ocorre entre liberdade e natureza, e não entre liberdade e necessidade, ou entre a vontade ut natura e a vontade ut libera. Pois, assim como o intelecto, a vontade inclina-se naturalmente para a necessidade. Entretanto, a vontade pode conseguir resistir à inclinação.

Retomando a objeção feita ao pensamento de Kant, lembramos da questão que Arendt faz ao Filósofo: “a razão então comanda a vontade?". Questão já levantada quando nossa autora reflete sobre Algumas questões de filosofia moral, ao analisar a filosofia prática de Kant. De acordo com Arendt, "Kant transformou algumas proposições presentes em sua Crítica da razão prática em imperativos para lhes dar um caráter de obrigatoriedade" (ARENDT, 2004, p. 134-135). Embora o conteúdo seja derivado da razão, adverte Arendt, considera-se que a forma imperativa é necessária, uma vez 
que a proposição racional se dirige à vontade. Arendt lembra-se das palavras de Kant em sua Fundamentação da metafísica dos costumes. "a concepção de um princípio objetivo, na medida em que coage uma vontade, é uma ordem (da razão), e a fórmula dessa ordem é chamada de imperativo". Desse modo, ela conclui que a vontade já não seria livre, mas estaria sob o ditame da razão, e diz:

A razão só pode dizer à vontade: isso é bom, de acordo com a razão; se quiser alcançá-lo, você deve agir de acordo. O que na terminologia de Kant seria uma espécie de imperativo hipotético ou nem seria um imperativo. E essa perplexidade não se torna menor quando escutamos que "a vontade nada mais é do que razão prática" e que "infalivelmente determina a vontade", de modo que devemos concluir que a razão determina a si mesma ou, como Kant concluiu, que "a vontade é a faculdade de escolher apenas o que a razão (...) reconhece como (...) bom" (Fundamentação da metafísica dos costumes) (ARENDT, 2004, 135).

A conclusão a que Arendt chega é que para Kant a vontade não passa de um órgão executivo para a razão, o segmento da execução das faculdades humanas, o que estaria em flagrante contradição com as primeiras palavras de Kant em sua Fundamentação da metafísica dos costumes. "neste mundo, e até também fora dele, nada é possível pensar que possa ser concebido como bom sem limitação a não ser uma só coisa: uma boa vontade" (KANT, 2008a, p. 21). Arendt observa que não apenas em Kant, mas em toda a filosofia depois da Antiguidade, existe a dificuldade de como persuadir a vontade a aceitar o ditame da razão. É evidente para a pensadora alemã que Kant pensou na boa vontade como aquela que ao escutar a pergunta "farás?", responderá "sim, farei!" E conclui que para descrever esta relação entre duas faculdades que claramente não são a mesma coisa, e, além disso, que não se determinam uma a outra de modo automático, ele introduziu a forma do imperativo categórico e sorrateiramente retomou o conceito de obediência. De acordo com as reflexões arendtianas Kant sabia que a vontade poderia dizer não à razão e introduziu uma obrigação.

De acordo com Jerome Kohn, ao concentrar seu interesse mais nas atividades de pensar e agir, do que nos seus resultados, Arendt dá um passo em direção à Kant, que em sua filosofia moral "localizava a liberdade em 
nossa motivação para agir, nossa decisão consciente não coagida de obedecer à lei moral da qual nós próprios somos o autor, a lei da liberdade e seu imperativo categórico" (KOHN, 2004, p. 21). Porém, nossa autora acredita que a liberdade humana, definida por Kant como autonomia, não depende da obediência à lei, que por definição nega à liberdade, mas do aparecimento no mundo de uma pessoa ou personalidade moral que encarna a lei. A experiência da liberdade, para Arendt, se realizava no processo de iniciação, em trazer algo novo ao mundo, não importa o que isso viesse a ser, pois não é possível conhecer de antemão os resultados do que estamos fazendo quando agimos com os outros. Lembrando que em Arendt o pensar é autoreflexivo, mas o agir se dá na presença de outros. Isto, a despeito do que Kant postulava, diferenciava estas duas atividades. Segundo Kohn,

Arendt concordava que essa pessoa kantiana (neste ponto a palavra "moral" é redundante) é constituída por si mesma na atividade da auto-reflexão, e nisso estava o seu problema. Quando essa pessoa aparece entre seus semelhantes, ela se mantém a parte deles no sentido de que só é responsável consigo mesma: para ela toda a inclinação, de fazer o certo assim como o errado, é uma tentação a que deve resistir. (KOHN, 2004, p.22).

Desse modo, o imperativo categórico talvez seja realmente o relato mais convincente já apresentado da noção tradicional de consciência moral. Entretanto, Kohn adverte que para Arendt, este imperativo derivado da lei universal da razão prática pura, capaz de distinguir entre o certo e o errado, era insuficientemente político pelo fato de o agente obediente não assumir a responsabilidade por seus atos. Assim, o caso do oficial nazista Eichmann, que agiu de forma explicitamente irrefletida e irresponsável, mostrou a Arendt que a noção de dever de Kant pode ser brutalmente deturpada. Como assinala André Duarte, a autora observou que Eichmann executara meticulosamente sua tarefa sem pensar, e motivado pelo desejo de seguir a regra que lhe fora proposta, e não inspirado por qualquer motivação ou convicção de ordem ideológica. Seu desejo era apenas o de obedecer a regra, incondicionalmente (DUARTE, 2000, p. 342).

Vale salientar que foi a percepção da total ausência de pensamento de Eichmann que atraiu o interesse de Arendt para as atividades espirituais, ou para as questões metafísicas, como "o que é o pensar?" ou "o que é o mal?", e 
ainda para a questão da liberdade da vontade, que direcionou o desenvolvimento desta exposição. Arendt acompanhou com perplexidade o julgamento de Eichmann, que ao ser interrogado pela polícia israelense respondeu que havia conduzido toda sua vida de acordo com os preceitos morais de Kant, e que havia agido segundo uma definição kantiana de dever.

\section{Considerações finais}

A guisa de conclusão, ressalta-se que o intento deste trabalho foi o de apontar aspectos das reflexões filosóficas de Hannah Arendt que se encontram em dissonância com a filosofia kantiana. Entretanto, longe de ser conclusiva, a pesquisa encontra-se ainda em estado bastante insipiente, e aponta a necessidade de aprofundamento e de desenvolvimentos posteriores.

Ao longo desta exposição, a tentativa foi a de evidenciar o esforço de Arendt para dar à faculdade da vontade o seu lugar de direito, por assim dizer. Nesse caso, contrária à Kant, a autora defende a tese de que a vontade é a fonte da ação e a responsável por trazer ao mundo algo novo, capacidade que faz parte da condição humana e que não deve ser considerada apenas um elo inserido em uma cadeia de causalidades.

Outro aspecto dissonante entre Arendt e Kant diz respeito à liberdade da vontade. Conforme aqui evidenciado, Arendt acredita que a vontade livre é sua própria causa, e não apenas um instrumento que segue os ditames da razão prática. Contudo, cabe lembrar, como bem o faz Suzanne Islas Azais, que "o problema da liberdade constitui o núcleo central da filosofia de Immanuel Kant” (AZAIS, 2008, p. 193). Sendo assim, para que se tenha a real dimensão das reflexões de Kant acerca desta temática será necessário considerar o conjunto de sua obra, já que em seu desenvolvimento intelectual o Filósofo deparou-se desde muito cedo com o problema da liberdade, questão complexa que não apenas orienta o curso da obra kantiana, mas da filosofia em geral. Questão complexa enfrentada também por Hannah Arendt, que em sua busca pela compreensão do mundo e dos homens, não se intimidou diante da magnitude da filosofia kantiana, questionando-a, e dando-nos desse modo um exemplo de sua independência, lucidez e coragem. 


\section{REFERÊNCIAS BIBLIOGRÁFICAS:}

ARENDT, H. Compreender: formação, exílio e totalitarismo (ensaios). Tradução de Denise Bottmann. São Paulo: Companhia das Letras; Belo Horizonte: Editora UFMG, 2008.

- A condição humana. $10^{\mathrm{a}}$ ed. Tradução de Roberto Raposo. Rio de Janeiro: Forense Universitária, 2001.

- Responsabilidade e julgamento. Tradução de Rosaura Eichenberg. São Paulo: Companhia das Letras, 2004.

$A$ vida do espírito. Tradução de Helena Martins (2 vol). Rio de Janeiro: Relume Dumará, 2002.

ASSY, B. "A atividade da vontade em Hannah Arendt: por um êthos da singularidade (haecceitas) e da ação”. In: CORREIA, Adriano (Org.). Transpondo o abismo: Hannah Arendt entre a filosofia e a política. Rio de Janeiro: Forense Universitária, p. 32 - 54, 2002.

AZAIS, S. I. "El descubrimiento del problema de la libertad en el proyecto filosófico de Kant". In: Studia Kantiana - Revista da Sociedade Kant Brasileira. N. 6/7, março de 2008, p. 193 - 205.

DUARTE, A. O pensamento à sombra da ruptura: política e filosofia em Hannah Arendt. São Paulo: Paz e Terra, 2000.

KANT, I. Crítica da razão pura. 6o․ ed. Tradução de Manuela Pinto dos Santos e Alexandre Fradique Morujão. Lisboa: Fundação Calouste Gulbenkian, 2008.

. Fundamentação da metafísica dos costumes. Tradução de Paulo Quintela. Lisboa: Edições 70, 2008a.

KOHN, J. "Introdução à edição americana". In: ARENDT, Hannah. Responsabilidade e Julgamento. São Paulo: Companhia das Letras, p. 7 - 30, 2004.

KRISTEVA, J. O gênio feminino: a vida, a loucura, as palavras - Tomo I Hannah Arendt. Tradução de Eduardo Francisco Alves. Rio de Janeiro: Rocco, 2002. 
PERIN, A. \& MORAES, S. "A teoria kantiana da causalidade por liberdade na Crítica da razão pura”. In: Disciplinarum Scientia - Série Ciências Sociais e Humanas, Santa Maria, v.2, n.1, 2001, p. 15-35.

YOUNG-BRUEHL, E. Por amor ao mundo. Tradução de Antonio Trânsito. Rio de Janeiro: Relume Dumará, 1997. 